\title{
Inhalt, Vol. 5, No. 3, 1982
}

\section{Contents}

Buchbesprechungen 114

Impressum 115

Dadak, Ch.; Nikorovicz, F. und Beck, A., Wien

Zum Problem der Arbeitsfähigkeit nach Radikalopera-

tion des Zervixkarzinoms 116

Voigt, H.; Meigel, W. N.; Meißner, K.; Mensing, H.;

Medenwaldt, B., Hamburg, und Jensen, G., Stade

Erfahrungen mit der hochdosierten Cis-Platin-Therapie

beim metastasierten malignen Melanom 120

Mross, K.; Mross, B., Göttingen, und Wolfrum, D. I., Bad Sooden-Allendorf

Der Leukozyten-Migrations-Inhibitionstest unter Ver-

wendung von basischem Myelinprotein bei Patienten

mit malignen Erkrankungen 130

Wagner, G. und Winter, G., Wien

Fotografische Auswertung des Elektrophorese-Mobili-

tätstests - Eine Modifikation - 135

Sonderbände 144

Mende, S.; Bleichner, F; Meuret, G.; Vogel, K.-H., Ravensburg, undHofmann, A., Wangen

Therapieergebnisse beim kleinzelligen Bronchialkarzi-nom an einem nicht selektionierten

Patientenkollektiv . . 146

Bürkle, V., Tubingen, Bürkle, G., Donaueschingen, und

Zielke, R., Osnabrück

Gewebsspezifität der Bleomycinwirkung.

Autoradiographische Untersuchungen

Hinweise für Autoren 158

Onkologie-Mitteilungen 159

Book Reviews 114

Imprint115

Dadak, Ch.; Nikorovicz, F, and Beck, A., Wien

The Duration of Sick Leave following Radical Surgery for

Cervical Cancer 116

Voigt, H.; Meigel, W. N.; Meißner, K.; Mensing, H.;

Medenwaldt, B., Hamburg, and Jensen, G., Stade

Experiences with Cisplatin-High-Dose-Therapy in

Advanced Malignant Melanoma

120

Mross, K.; Mross, B., Göttingen, and Wolfrum, D. I., Bad Sooden-Allendorf 
Cellular Immunity to Myelin Basic Protein (MBP) in

Patients with Malignancies as Measured by the Leukocyte

Migration Inhibition Test (LMI-Test) 130

Wagner, G. and Winter, G., Wien

The Photographic Evaluation of the Electrophorese-

Mobility-Test (EMT) - A Modification - 135

Special Editions 144

Mende, S.; Bleichner, F; Meuret, G.; Vogel, K.-H.,

Ravensburg, and Hofmann, A., Wangen

Combined Treatment of Small Cell Lung Cancer in Un-

selectioned Patients 146

Bürkle, V., Tubingen, Bürkle, G., Donaueschingen, and

Zielke, R., Osnabrück

Tissue Specificity of the Bleomycin Action.

Histoautoradiographic Studies

150

Instructions for Authors 158

Oncology Communications 159

Bibliographischer Hinweis: Inhaltsverzeichmsse dieser Zeitschrift erscheinen regelmäßig in current contents ${ }^{\circledR}$ sowie in anderen bibliographischen Diensten. 